\title{
Action learning: how learning transfers from entrepreneurs to small firms
}

Article

Accepted Version

Jones, K., Sambrook, S. A., Pittaway, L., Henley, A. and Norbury, H. (2014) Action learning: how learning transfers from entrepreneurs to small firms. Action Learning: Research and Practice, 11 (2). pp. 131-166. ISSN 1476-7333 doi: https://doi.org/10.1080/14767333.2014.896249 Available at https://centaur.reading.ac.uk/46445/

It is advisable to refer to the publisher's version if you intend to cite from the work. See Guidance on citing.

Published version at: http://dx.doi.org/10.1080/14767333.2014.896249

To link to this article DOI: http://dx.doi.org/10.1080/14767333.2014.896249

Publisher: Taylor \& Francis

All outputs in CentAUR are protected by Intellectual Property Rights law, including copyright law. Copyright and IPR is retained by the creators or other copyright holders. Terms and conditions for use of this material are defined in the End User Agreement.

\section{www.reading.ac.uk/centaur}

\section{CentAUR}

Central Archive at the University of Reading 
Reading's research outputs online 
Jones, K., Sambrook, S., Pittaway, L., Henley A. and Norbury, H. (2014) 'Action Learning: How Learning Transfers from Entrepreneurs to Small Firms', Action Learning: Research and Practice. Vol. 11, No. 2, pp. 131-166. http://dx.doi.org/10.1080/14767333.2014.896249

\section{Action Learning: How Learning Transfers from Entrepreneurs to Small Firms}

The paper presents research with small and medium enterprise (SME) owners who have participated in a leadership development programme. The primary focus of the paper is on learning transfer and factors affecting it, arguing that entrepreneurs must engage in 'action' in order to 'learn' and that under certain conditions they may transfer learning to their firm. The paper draws on data from 19 focus groups undertaken from 2010 to 2012, involving 51 participants in the LEAD Wales programme. It considers the literatures exploring learning transfer and develops a conceptual framework, outlining four areas of focus for entrepreneurial learning. Utilising thematic analysis, it describes and evaluates what (actual facts and information) and how (techniques, styles of learning) participants transfer and what actions they take to improve the business and develop their people. The paper illustrates the complex mechanisms involved in this process and concludes that action learning is a method of facilitating entrepreneurial learning which is able to help address some of the problems of engagement, relevance and value that have been highlighted previously. The paper concludes that the efficacy of an entrepreneurial learning intervention in SMEs may depend on the effectiveness of learning transfer.

Keywords: action learning; SMEs; entrepreneurial learning; learning transfer 


\section{Introduction}

Action learning is becoming recognised as an important programmatic approach for encouraging and enhancing entrepreneurial learning (Gibb 1997; Devins and Gold 2000; Clarke et al. 2006; Pittaway et al. 2009; Thorpe et al. 2009). This paper considers how action learning impacts on entrepreneurs and explains how such learning transfers to the small firm itself. The paper's main focus is within the context of a leadership programme for entrepreneurs introduced in Wales over the period 2010 to 2012 . The paper investigates how action learning facilitates learning for entrepreneurs, considering learning transfer and factors affecting it in order to gain greater insights into how entrepreneurs 'take forward' their personal learning (Cope 2005) and the techniques they use (or not) to apply their learning within the context of their firm, through employees and other stakeholders (Jones, Macpherson and Thorpe 2010).

Research into how entrepreneurs learn has increased over the last decade (Cope 2010). Although there is agreement that programmes need to be problem centred and linked to the development needs and contextual tasks of the entrepreneur, there is little evidence of how learning transfer can be achieved in practice (Gibb 2009). Research on learning transfer largely focuses on how off-the-job employee training is applied in the organisation. Little is known about how entrepreneurial and leadership learning is transferred back to the organisation and less is known about the mechanisms involved (Jones, Macpherson, and Thorpe 2010). The paper seeks to narrow this gap. The paper begins by outlining the importance of action learning for entrepreneurs. Next the paper summarises key themes from the learning transfer literature and explores contemporary thinking about entrepreneurial learning. A conceptual framework with four areas of focus for entrepreneurial learning is presented, and then a brief introduction to the 
programme and its action learning elements is discussed. The remainder of the paper explains the methodology and presents the findings, showing how individual entrepreneurial learning can be transferred within the small firm. The paper concludes by outlining some of the key mechanisms at work in the transfer of learning from an action learning programme.

\section{Action learning and entrepreneurs}

Action learning in entrepreneurship has grown in importance in recent years (Clarke et al. 2006; Pittaway et al. 2009; Thorpe et al. 2009) for two interrelated reasons. First, while action learning programmes for entrepreneurs have proved their efficacy (Clarke et al. 2006; Pittaway et al. 2009) they have not replaced the dominant paradigm of business support or management development for small firms (Devins and Gold 2000), with its various recognised problems. Advocates of action learning highlight the weaknesses of traditional approaches and present action learning as an alternative (Pittaway et al. 2009; Pittaway and Thorpe 2012). The problems include:

(1) A problem of engagement - entrepreneurs often fail to engage with traditional methods of business support and despite being offered cheap or free training often fail to take it up (Stanworth and Gray 1991; Storey 1994; Westhead and Storey 1996).

(2) A contextual problem - traditional programmes are 'supply orientated' rather than 'demand orientated' (Dalley and Hamilton 2000; Pittaway and Thorpe 2012). They struggle to meet what is required by entrepreneurs whose learning needs can vary by the: types of firm; problems experienced; entrepreneur's motivation; stage of growth; and, by the immediacy of the issues being addressed (Clarke et al. 2006). 
(3) A problem of value - entrepreneurs usually struggle to see how programmes can help their business, understanding that the opportunity costs of their time are high (Perren and Grant 2001). Consequently, programmes must demonstrate performance benefits for the entrepreneur or their business, which traditional programmes often fail to do (Thomson et al. 1997).

Action learning has been observed to address these problems in several ways (Gibb 1997). The problem of engagement is solved by enabling learning to be driven by the entrepreneurs' practical needs to share experiences, to learn from others' problems and to explore practical solutions to their own problems (Pittaway et al. 2009), which allows learning through action (Cope and Watts 2000). The contextual problem is solved by allowing the curriculum to emerge from the entrepreneurs' own issues and the contexts they face on a daily basis with flexibility to focus on immediate needs when necessary (Westhead and Storey 1996; Thorpe et al. 2009). Meanwhile, the problem of value is addressed by action learning's utilization of peers, where entrepreneurs can learn from authentic experts (i.e. other entrepreneurs) who have entrepreneurial credibility and are drawn from their immediate 'community of practice' (Clarke et al. 2006).

Although action learning has many benefits and can be used to assist entrepreneurial learning, it is not without its limitations. It can, for example, be resource intensive and time consuming (Ingram et al. 2000). For entrepreneurs undergoing rapid growth or just starting out it can be difficult to set aside the time to engage appropriately. Pressing business needs can sometimes get in the way of active participation, and damage the learning process for all 
involved (Stewart 2009). The nature of the group dynamics within an action learning set can also have ramifications for the quality of the learning experience. Sharing sensitive data, business and personal challenges and being open about personal deficiencies, requires a high of level of trust in the other participants and so a lack of trust or poor group dynamics can also restrict the value of action learning for entrepreneurs (McNeill, Lawson, and Mulhaney 2012). Likewise action learning programmes rely on effective facilitators to lead discussions and ensure underlying alignment with the sought after learning design (McGill and Beaty 2001). Poor facilitation is a recognised problem that can reduce the benefits of action learning (McNeill, Lawson, and Mulhaney 2012). Poor implementation of action learning as a consequence of bad facilitation can lead to learning sets becoming mere support groups (Pedler 1997). Despite the risk, within the context of entrepreneurship, this remains an important function, as entrepreneurs often report being isolated and feeling alone, and so mutual support is an important component of what action learning offers entrepreneurs (Inglis 1994; Clarke et al. 2006). Other criticisms of action learning suggest that it is atheoretical (Pedler 1997), that it is too focused on individual learning and the individual as the agent of change (Waddill and Marquardt 2011), and that it mobilizes current organisational power structures rather than allowing for critical thought and radical change (Pedler 2008). Although these are valid criticisms, within the context of entrepreneurship, the focus of action learning is to allow entrepreneurs to examine and address practical problems within their own business context. Learning within such sets is typically social (Bandura 1977, 1986) because it involves entrepreneurial peers and as our study will show, learning is often co-constructed or shaped by set members and by others within the context of the firm (Smith 2012). If facilitated correctly and carried out well it should support social action and not impede it. 
As with all forms of learning, action learning has both strengths and weaknesses and both advocates and detractors. Past research has shown that despite some of the weaknesses, if action learning is implemented correctly, it can help address the recognised problems of engagement, context and value (Clarke et al. 2006). Ultimately, it can be used to assist entrepreneurial learning and so next the paper explores how entrepreneurs learn and how such learning drawn from being involved in action learning can transfer from the individual to the firm.

\section{Learning transfer}

Traditional conceptualisations of action learning as emergent and negotiated may be interpreted as problematic within a discussion on learning transfer, which is generally concerned with learning events or specific learning outcomes. Nevertheless, Kirwan (2009) suggests the link between action learning and learning transfer lies in the philosophy of action learning, and its desired outcome that it will cause the learner to do something different (Johnson 1998, 297). 'Doing things differently' may involve new ways of framing, new perspectives, new language or new ways of thinking about work (Rigg 2005, 64). In the context of leadership development, research has shown that learning transfer can be optimised through action learning (Leonard and Lang 2010). Fundamentally, because it generates actionable solutions, for which individuals are accountable, to real and important practice related problems, it provides the necessary conditions for transferrable learning (Hicks and Peterson 1999). Learning transfer may continue beyond the individual learner, affecting staff, both individually and collectively in their work practices largely informally, through micro-processes of development that take place through everyday 
social interactions, patterns of organising, and daily experiences talking about and doing work (Rigg and Trehan 2002).

Nevertheless, a review of the literature on action learning research highlights that the link with learning transfer is under developed (Cho and Egan 2009). Furthermore, research on the question of learning transfer is largely confined to learning transfer in large organisational settings. It tends to focus on organisational learning in both a formal and an informal sense and spans a range of domains and learner contexts. Theories of learning transfer emphasise the importance of a range of factors, including the motivation of the learner to transfer learning, the opportunity for transfer, and the context into which that transfer might take place (Baldwin and Ford 1988; Holton 1996; Yanmill and McLean 2001; Merriam and Leahy 2005; Gilpin-Jackson and Bushe 2007). Particularly within the entrepreneurial context, where the literature is relatively sparse, the possibility of learning transfer is embedded in the notion of dynamic learning (Cope 2005) and is viewed to depend on the development of interdependent relationships within the firm and with external stakeholders (Holman et al. 1997; Deakins and Freel 1998). Broad defines learning transfer as the:

‘...effective and continuing application by learners-to their performance of jobs or other individual, organisational, or community responsibilities-of knowledge and skills gained in the learning activities'(1997, 2).

This definition reflects the diversity of learning activities available to adults and the wide range of contexts where they may transfer their learning (Merriam and Leahy 2005). For 
entrepreneurs flows of transfer may occur at various levels in the organisation, within the business community, and at a wider societal level, for instance with other organisational stakeholders (Jones et al. 2013).

Regardless of the setting to which learning is transferred a prevailing issue reported by researchers is the dismal rate of learning transfer, now referred to as the 'transfer problem' (Saks and Belcourt 2006). In an early review of the literature on learning transfer Tannenbaum and Yulk (1992) found as few as 5\% of learners transferred their learning to the work place. Possibly in response to this problem more programmes are designed with transfer in mind. Yet the importance of transfer to adult learning is still highly topical and important (Foley and Kaiser 2013). More specifically when exploring entrepreneurial learning, Gibb has also drawn attention to the 'transfer problem', noting in programme evaluation 'there is often a demonstrable marked absence of a capacity to transfer the 'learning' into the 'how to' of 'doing' in the context of the business' $(2009,210)$.

Unsurprisingly this problem has prompted voluminous studies into factors that may facilitate or hinder transfer. In a review of the empirical research from 1990 to 2005, Merriam and Leahy (2005) found the largest concentration of these studies to be in the training and human resource development journals. These tend to focus on the transfer of skills acquired in school or work training. Merriam and Leahy (2005) note comparatively few contributions from researchers of adult education, indicating a need for research on learning transfer in many subject areas including action learning and entrepreneurship. In terms of assessing the key factors influencing 
the nature of learning transfer some interesting insights and overlaps can be identified that are valuable for the study reported here.

Firstly, with regard to personal characteristics, individual motivation is widely cited as an important variable affecting learning transfer (Blume et al. 2010; Burke and Hutchins 2007; Fraziz, Gittleman and Joyce 2000; Mathieu, Tannenbaum and Salas 1992). Pre-training motivation is also identified as a predictor of learning transfer (Facteau et al. 1995). Research has also explored individual self-efficacy (see for example, Blume et al. 2010; Colquitt, Lepine and Noe 2000; Velada et al. 2007) and has found that those who have higher self-efficacy are more confident in their ability to transfer learning and are thus more likely to persist with their efforts. Further, findings from a recent study of participants in a leadership development programme revealed that 'individual characteristics' were a strong predictor of learning transfer because participants' preparedness for learning and motivation led them to apply their learning if they believed they could change their performance (performance self efficacy) and make improvements (transfer-effort performance expectations) that they valued (performance-outcome expectations) (Waller, 2012).

Other research suggests that a second variable influencing learning transfer is programme design (Burke and Hutchins, 2007). It has been argued that to increase the likelihood of transfer programmes should create a realistic learning environment, which resembles the workplace (Burke and Hutchins 2007; Kraiger 2003; Waller 2011). This argument also resonates with the research about entrepreneurs and their learning, principally the view that training interventions need to be relevant to the ongoing business needs of the business itself (Gibb 1997; Gold and 
Thorpe 2010). The implication is that transfer is much easier in situations that are closely intertwined with the immediate context for the learner. Detterman (1993) distinguishes this as 'near' and 'far' transfer. Learning activities that are the same or close to work activities are more likely to be transferred (near transfer).By contrast, far transfer involves situations that are different, causing the learner not to fully understand the connection between contexts and, therefore, the opportunity to transfer learning. Waller (2011) suggests learning activities that promote transfer include opportunities to reflect on learning, opportunities for peer feedback, group work, and opportunities to practice learning.

The third key aspect of the learning transfer research is the work environment itself. The climate and culture of the work environment plays an important role in transfer (Rouiller and Goldstain 1993; Tracey, Tannerbaum, and Kavanagh 1995). For instance, the likelihood of learning transfer is increased in an environment where individuals are encouraged to try out and share new skills. By contrast, resistance to change within the work context can impede learning transfer (Waller 2011, 2012). The role of managers and peers (work colleagues) feature prominently in the transfer literature. Given that the entrepreneurial context is generally directed by the vision and influence of the entrepreneur (Gartner, Bird, and Starr 1992), the work culture and relationships created in the firm may play an important role in learning transfer. Peer support (Rouiller and Goldstain 1993) or social support also appears to play a central role in transfer (Facteau et al. 1995; Tracey, Tannenbaum and Kavanagh 1995), and this can emerge from both the learning environment and the work context. 
Within entrepreneurial businesses, the small size of the firm and its inherent informality (Penn et al. 1998) may both help and/or hinder learning transfer. The diffusion of tacit to tacit or explicit to explicit knowledge may be less challenging in smaller businesses where communication lines are short and entrepreneurs can directly communicate with employees. It may be more challenging, however, when the transfer of learning includes the translation of tacit knowledge held by the entrepreneur into explicit knowledge for the firm, which offers generative potential (Anderson and Skinner 1999). Such capacity for double-loop learning can underpin change in the business and has been considered to offer sustained benefits for learning beyond the individual (Cope 2005). Learning that starts with the individual entrepreneur, transfers to employees and becomes institutionalised into the ongoing practices of the firm has been seen to be of instrumental importance as firms develop and grow (Anderson and Skinner 1999). Yet, although there is a vast literature on learning transfer, there is little consensus about the key factors and only limited research on this aspect within entrepreneurship. Consensus does seem to revolve around agreement over the impact of individual tendencies, programme design and the work environment, but exact details of how they impact transfer is yet to be fully explored in the entrepreneurial learning context. As a consequence, the following section will expand the discussion of learning transfer by introducing the research on entrepreneurial learning where it explores how transfer has been considered previously.

\section{Entrepreneurial Learning}

Research on entrepreneurial learning has expanded over the last decade or so and it is now quite extensive (Gibb 1997; Rae 2000; Cope 2005). Early studies focused principally on the individual entrepreneur and their learning (Taylor and Thorpe 2004; Leitch and Harrison 2005), 
through experience (Deakins 1996; Smilor 1997; Reuber and Fischer 1999) or focused on learning tasks (Minniti and Bygrave 2001). Much of this early work did not focus on learning transfer and inevitable questions were raised about whether experiences lead people to change their behaviour (Rae and Carswell 2001). More nuanced studies followed that explored the role of reflection (Cope 2005). It was argued that simply doing was not enough, how entrepreneurs reflected on their experiences was also critical in ensuring deeper learning could occur, leading to a more useful 'stock of experience' on which entrepreneurs could draw (Reuber and Fischer 1999; Cope 2005). As work on individual entrepreneurial learning gathered pace, research began to focus on transformative learning events, such as crises (Cope 2010). Research explored how non-routine events led to heighten emotional states, which encouraged individuals to question their current self-perceptions leading to transformative learning outcomes (Deakins and Freel 1998; Cope 2003; Cope 2010). This strand of work has led to a greater focus on the emotional aspects of learning and on events, such as business failure, and has also led to a greater appreciation of the social dynamics of learning (Cope 2010). These concepts from within the entrepreneurial learning literature helped inform this study. Four areas are identified as being particularly important in guiding our data analysis on entrepreneurial learning and its transfer to the firm.

\section{Learning by doing}

Much of the early research in entrepreneurial learning focused on randomness, experimentation and the dynamic aspects of the entrepreneurial context. As the entrepreneurial context was considered to be dynamic and ever-changing entrepreneurs were considered to have to learn through trial and error, by trying things out (Woo, Dallenbach and Nicholls-Nixon 1994). This concept is linked to the central idea in action learning that taking 'action' is 
imperative for learning to occur (Vince 2008). It was anticipated that entrepreneurs would take forward their activities, test them in practice, and consequently learn as they did so (Smilor 1997). Such learning by doing has a number of identifiable components. Entrepreneurs get involved with new learning tasks every day (Smilor 1997). Due to resource constraints they often have to engage in technical and tactical learning tasks as they run their venture and as the tasks emerge (Boud, Keogh, and Walker 1985; Minniti and Bygrave 2001, Penn et al. 1998). This learning as you go may occur in many areas, for example: learning about oneself; learning about the business as it is created; learning about leadership and management of others; and learning about the context the business operates in (Sexton et al. 1997; Gibb 2002). As entrepreneurs learn through these daily tasks they become more competent and confident in their ability to engage in actions and when faced by uncertain situations or ambiguity can have a heightened 'preparedness to act' (Harvey and Evans 1995). So, for example, more confident and/or experienced entrepreneurs are seen to more regularly engage in serial entrepreneurship and apply learning acquired from prior efforts because these experiences provide them with confidence and increase their preparedness to engage in future opportunities (Reuber and Fischer 1999). Actions taken by entrepreneurs, however, can have unintended consequences, outcomes that could not have been easily anticipated beforehand (Gibb and Ritchie 1982; Deakins 1996). The research on learning by doing suggests that more effective entrepreneurs are those that have the prior 'stock of experience' from which they can carefully consider actions and their possible consequences and that such entrepreneurs may have an ability to anticipate problems and proactively address them before they become consequential to the firm's survival (Cope 2005). The research on learning by doing seems to clearly indicate that entrepreneurs gain experiences from ongoing operations that ultimately enhance their preparedness to take actions and such 
experience improves their judgments over time (Reuber and Fischer1999). What this literature does not seem to address though is how these competencies are transferred to others in the firm; particularly as the entrepreneur takes on more people and expands the business.

\section{Reflective Learning}

Over the years research on entrepreneurial learning has highlighted a paradox in the research on learning by doing. It is clear that a person can engage in actions, have experiences and yet they may not necessarily learn from those experiences (Gibb 1997). Consequently, reflective practices have been highlighted as an important component in the learning process for entrepreneurs. It has, for example, been argued that entrepreneurs who are effective learners may be more sophisticated in their reflections of critical experiences and that these reflections allow for an entrepreneur to become more competent (Cope 2005). Such reflective practices carried out by entrepreneurs, it is argued, allows them to take forward their learning, enables them to become more competent as entrepreneurs and helps guide their future actions (Gibb 1997). In turn entrepreneurs may change their own behaviours and interactions with others. This may lead them to become more strategic or allow them to become more financially astute. So, the literature argues that reflective learning can lead to change, in how an individual see themselves, and how they interact with the context in which they operate (Cope 2005). This stream of research would suggest that more reflective entrepreneurs are perhaps more likely to transfer learning to their employees and institutionalise learning into the business. As they reflect on themselves, on their interactions with others and on how the firm operates, they are perhaps more able to have insights that they can share. How such reflective practices can be 
transferred to other individuals or institutionalized within the context of the firm itself though, have not been subjects of concern and as such, they offer interesting avenues for future study.

\section{Social Learning}

Prior work on learning by doing and reflective learning has been criticized for lacking a social aspect (Hines and Thorpe 1995). Most research has focused on the individual learning and individual entrepreneurs and yet it has been argued that learning for entrepreneurs, as with other people, is inherently a social process (Tell 2000; Devins and Gold 2000; Penn et al. 1998) and decision-making in entrepreneurial ventures are often collaborative or at least guided by the entrepreneur's wider networks (Hines and Thorpe 1995). This social component of learning may be of particular importance when exploring the transfer of learning. Such transfer may materialise in a variety of ways for example, engaging with key others in the supply network; seeking out consensus with employees (Smilor 1997); testing thoughts out with a spouse or talking to important mentors. These social aspects of learning are clearly critical and perhaps underappreciated in the current literature on entrepreneurial learning. Trust, respect and shared experiences become important drivers that can guide entrepreneurial actions and encourage learning between individuals. When exploring how learning might transfer between the entrepreneur and the firm then such social aspects are essential to consider (Jones, Macpherson, and Thorpe 2010).

\section{Emotion and Affective Learning}

As research has progressed in recent years and begun to focus more on the social aspects of learning, affective learning and emotional exposure have featured more often within studies 
(Pittaway and Cope 2007). Social learning is inherently affective learning, as interactions between people involve the experience of a diversity of emotions, which are linked to the relationships and their history (Baker, Andriessen, and Järvelä 2013). Entrepreneurial endeavour itself, is an inherently emotional journey, as entrepreneurs are recognised to experience forms of emotional exposure linked to owning a business (Cope 2005). These include, financial exposure derived from taking personal financial risks, relationship risk derived from the pressures an entrepreneurial life can create for the family and social risk from the consequences of failure (Cope 2010). Such exposures can create both heightened levels of emotions for entrepreneurs and encourage a greater degree of learning, as certain experiences can be more intense. Consequently, the emotional character of learning may be an important consideration when seeking to understand how learning is transferred from individuals to the firm and this is clearly mirrored in the literature on learning transfer which considers the role of the workplace (Burke and Hutchins 2007; Kraiger 2003). Likewise certain crises or events that have higher levels of emotionality (for example, a near death experience for the business) may be critical in helping to explain how significant learning occurs and/or leads to effective transfer of learning or change for the venture itself (Cope 2010).

These concepts in entrepreneurial learning summarise some of the key aspects of the literature that have guided our study and subsequent data analysis. As the paper progresses it will explore the transfer of learning and the evidence of non-transfer from the LEAD Wales programme based on these concepts. The programme is briefly described next. 


\section{The LEAD Wales programme}

LEAD Wales is a European Social Fund project funded from Wales EU Convergence Funding with match funding from the higher education delivery partners, Swansea and Bangor Universities. It aims to provide leadership development to 700 small and medium-sized enterprises (SMEs) across Wales between 2009 and 2015. It adopts a design developed and piloted from 2004 onwards for the North West region of England as a partnership between the former North West Development Agency and Lancaster University, and is based on the same principles of entrepreneurial leadership learning (Kempster and Watts 2002; Kempster 2009 Peters 2010; Smith and Peters 2006). The programme promotes the development of leadership skills and the ability to transfer learning from the programme into practical workplace applications. At the programme core is a learning philosophy built around action learning (Revans 1980, 1993; Thorpe et al. 2009).

Participants are recruited in groups of approximately 24 at a time. The programme consists of various core activities incorporated in an integrated learning model (Figure 1). These include a two day residential experiential learning event, a series of ten half-day interactive Masterclasses (five on leadership and five cover functional management subject areas), six action learning set sessions, peer-to-peer shadowing and exchange activities and five individual business coaching sessions. These elements are intertwined over the 10 month programme to aid participants in learning and business development.

\section{$<$ Figure $1>$}


In contrast to many management and leadership development programmes, there is limited formal curriculum (Gibb 2009). Programme content is relatively 'participant-led' as Masterclass themes are based on participant needs or challenges. The programme is underpinned by a philosophy of social learning and it encourages critically reflexive practice. This means examining critically the assumptions underlying individual actions, the impact of those actions, and what passes as good practice (Cuncliffe 2004, 407). However, a unique feature of action learning is that the focus is on critical reflection as a collective activity that provides opportunities for participants to undertake contextually specific inquiry into real life organisational situations and problems (Reynolds 2011, 12). Thus the programme creates an

environment where participants are able to freely discuss their hesitations and articulate a successful way forward with business issues and take action where appropriate in the business context (Jones et al. 2013). Previous research has established this can be highly effective in an entrepreneurial learning context (Stewart 2009; Leitch, McMullan, and Harrison 2009), in particular, delivering improvements in personal confidence and individual learning.

\section{Methodology}

To gain a rich understanding the research employed a qualitative approach, approved by both universities' ethics committees. Focus groups were conducted for effective use of time and, because they are less artificial, they are more likely to reveal participants' points of view than a traditional individual interview (Wilkinson 1998, 1999). Furthermore, focus groups encourage discussion and interaction among participants (Kitzinger 1994), and thereby continued the peerto-peer learning upon which the programme is based (Henley and Norbury 2011). A semi- 
structured questioning approach was adopted, with open-ended questions and the following themes were discussed with and among the participants:

(1) Feedback describing their experiences in the programme;

(2) Key learning as both an individual and a business leader;

(3) The impact of learning on their business;

(4) The impact of learning on their employees.

One limitation of this approach is that it relies on participants' own perceptions of the impact of their learning. However, these themes allowed for additional questioning to gain further clarification on the concepts underpinning our study and on ideas and examples of individual learning, methods of transferring that learning into the organisation and action taken in the business.

For two years focus groups were conducted with each group of participants that completed the programme. A convenience sample was used. Two months after programme completion, emails were sent to corresponding participants inviting them to take part. Of the 236 invited to attend, 51 individuals agreed to assist, resulting in a 22 per cent response rate. The sample of 36 males (71\%) and 15 females (29\%), broadly reflects the $66 ; 34 \%$ male-female ratio in the programme. Each session had, on average, three participants and lasted 60-90 minutes. With participants' permission, the focus groups were audio recorded, allowing interviewers to focus on the participants and not on note taking. This technique created 'conversations' that retained the tone of the programme and produced open and candid responses. 


\section{Data analysis and results}

Focus group sessions are more time consuming to transcribe than personal interviews (Bloor et al. 2001) due to the vast amount of data they produce (Bryman 2004). Consequently only 13 of the 19 sessions were transcribed to verbatim, with all participants' names fictionalised. Key themes and quotes were transcribed from the remaining audio recordings. This resulted in over 121,000 words of text. Two experienced qualitative researchers (anonymised for review) undertook data analysis. For rigor they drew on an approach developed by Armstrong et al. (1997) known as inter-rater reliability. This can be viewed as a form of auditing (Lincoln and Guba 1985). The processes involved were iterative rather than linear (Ram and Trehan 2010), taking the form of cycles of inquiry back and forth between the researchers and their interpretations of different categories of coding at each stage of analysis. Prominent themes were extracted, using thematic analysis (Boyatzis 1998). These were thematically coded (Yin 1989), initially as eight areas of entrepreneurial learning, which were then categorised thematically into the four concepts discussed in our conceptual framework: learning by doing, reflective learning, social learning, and emotion and affective learning. The coding of the data (including counting the number of words per category) is outlined in Table 1. This shows that learning by doing is particularly evident in the data, followed in frequency by emotional and affective aspects of learning, and with comparable results for reflective learning and social learning.

< Table 1> 
Another cycle of coding was undertaken to draw out secondary themes, of which there were 38 . An 'adequate stock of descriptions' (Martin and Turner 1986, 143) of the phenomenon in question was gathered and analysed to make sense of the data categories (See Appendix 1). This was then compared and contrasted with the results from the literature review and the four concepts discussed. Once more, the processes involved were iterative rather than linear (Ram and Trehan 2010), and involved discussion between the researchers at each stage.

\section{Findings and discussion}

The findings provide key insights on the transfer of learning and non-transfer between the entrepreneur and their firm. These are discussed according to the four conceptual areas in entrepreneurial learning presented previously and drawing on the general transfer of learning literature as the implications of the data are discussed.

\section{Learning by doing}

In keeping with the learning transfer literature participants expressed a strong preference for contextually relevant activities that they could take forward and apply in their businesses (Burke and Hutchins 2007; Kraiger 2003; Waller 2011, 2012). Although a minority felt that aspects of the programme lacked relevance, the majority deemed it to be highly relevant and in such cases the different elements of the LEAD 'curriculum' encouraged the participants to take what they had learnt back to their businesses and experiment; trying something new to see how it works. There was a strong learning by doing mentality amongst the participants that included using aspects of the curriculum within their businesses (Minniti and Bygrave 2011). The following participant sums this up well: 'you can use it... you could break it down into what you needed'. 
Participants felt they could easily understand the connection between the programme and their ongoing business efforts and could see the opportunity to transfer learning between domains. Outcomes from this part of research offered some confirmation of Detterman's (1993) concept of 'near transfer'. It was evident that the design of the LEAD programme was considered to be close enough to the entrepreneur's day to day work context that entrepreneurs accumulated learning that had a contextual value, which was considered to be transferable (Westhead and Storey 1996; Thorpe et al. 2009).

Elicited from the data were key themes or 'learning tasks' regarding participants' learning that resonate with Cope's work (2005): personal learning (learning about oneself); leadership learning (learning about the nature and management of relationships), and learning about the business, the environment and networks all featured extensively. Personal and leadership learning is prominent in the data:

\begin{abstract}
'It has made me a better person - understanding me and then understanding [my business partner] and... I think it's made me understand the employees better and I think if I understand the employees better and the contribution they can or they can't make to the firm then I'm going to understand better the direction of the firm and how to achieve it.'
\end{abstract}

Once more, confirming themes in the learning transfer literature, participants were motivated with their learning because believed they could change their performance and make improvements that believed were of value (Waller, 2012). Masterclass sessions on topics such as branding, marketing, public relations and business finance prompted participants to focus their efforts on functional or strategic aspects of their businesses; illustrating they saw value 
connected to ongoing business operations (Thomson et al. 1997). By contrast, other participants experimented with both leadership and functional aspects of personal learning and deliberately sought to transfer it (Gibb 2009). For instance, some would retell the key message of the session to their staff and involve them in taking ideas forward, adopting a more distributed leadership style (Kempster, Cope, and Parry 2010), whilst also imparting their learning about functional aspects (Sexton et al. 1997). One participant provides a good example:

\footnotetext{
'I actually took the ideas that we did here, especially on branding and looked at our business... I put it to the guys to take control of these plans and ideas and brainstorming. And we did a presentation day. What I did so I wouldn't get involved at all... we'd all vote on each other's and ideas for the business segments... It was a phenomenal day and from those ideas, we've now segmented one business completely and started a new company... All those were ideas of the guys where I had no input what so ever. It all came from the floor.'
}

A small minority did not take any immediate action to transfer learning to the firm and expressed regret about this; viewing it as a lost opportunity. It was, however, recognised that the opportunity for transfer had not been lost, since these participants preferred to take longer to reflect on learning before taking action. They had perhaps developed a 'cognitive store' (Cope $2005,386)$ which they could use in future. This point has great value as, it allows entrepreneurs to enhance their 'preparedness to act' (Reuber and Fischer, 1999) as the business develops and presents the opportunity or 'strategic window' (Abell 1978). Sensitivity to change and opportunity is often viewed as an ingredient of entrepreneurial success and the entrepreneur must be prepared and know when to act (Harvey and Evans 1995, 344; Smilor 1997). Yet, the economic downturn and other setbacks impinged on many participants' ability to act or even plan for the future, illustrating that contextual issues do play a part in learning transfer (Gibb 
2009). Others revealed they were in a 'rut'. It is, therefore, promising that the programme boosted confidence to overcome setbacks and in many cases re-ignited an entrepreneurial spirit, as illustrated by this person: 'whoof sort of reasserted myself and it's given me a line now where I want to go for the next sort of four or five years. My confidence has definitely grown on it.'

In keeping with other research, the data reveals evidence of increased confidence related to increased self-efficacy, which is an important predictor of learning transfer (Blume et al. 2010; Waller 2011):

'The main thing has been the confidence - confidence to go where I hadn't gone before and new Worlds. But some of the things that have faced me, I've really taken other opportunities that I may not have taken, for example, looking a lot wider, possibly with a view to selling the business and taking on new opportunities. It's made me realise that I can keep my brain active and I want to develop new things and not keep in the comfort zone... I don't think I'd have had that sort of confidence. I was sort of in a rut... it's given me the confidence to stand back and look and plan more ... Now I've got a ten year plan of where I want to be and it's really given me the ability to do that and I don't think I would have had the bottle - I don't think I would have had my eyes on the horizon. My eyes were firmly on the floor and that's where it's changed me.'

The data did reveal that the work environment can mediate the success (or not) of learning transfer (Rouiller and Goldstain 1993; Tracey, Tannerbaum, and Kavanagh 1995), particularly due to resistance to change (Waller 2011; 2012). It is not always possible for entrepreneurs to anticipate the outcomes from actions taken in the business when attempting to transfer learning as such actions can have unintended consequences (Gibb and Ritchie 1982; Deakins 1996). The data confirms this and showing that a small minority of the participants experienced significant 
resistance from staff when they sought to implement change, as noted by this participant: 'Our staff morale has seemed to have gone; it's just gone to non-existent. They don't like change and now we're implementing change.'

\section{Reflective practices}

Providing opportunities for reflection is important for the facilitation of learning transfer (Waller 2011). The evidence of reflective learning in our data is consequently of particularly interest. Although reflection can come in different forms the emergent themes in the data seemed to resonate well with De-Fillipi's (2001) approach. Firstly, the data showed changes to personal awareness (Gibb, 1997) that created many changes in how participants ran their businesses and changed their approach to the way in which they treated their employees. The data thus showed many instances of 'observations of self in the context of the action' as highlighted in entrepreneurial learning (Cope, 2005). Second, learning about how other entrepreneurs ran their businesses and how they interact with their staff had an impact on many participants and prompted a number of 'observations of self in relation to others'. It encouraged some to reflect on themselves in relation to other participants and led to noticeable peer to peer learning benefits within LEAD cohorts (Clarke et al. 2006) as entrepreneurs sought to emulate each other. Third, participants were more aware of how their actions could impact on their staff's emotions (Kerr, Gavin, Heaton, and Boyle 2005) and this prompted learning from experience and changes in self-perception, as illustrated in the following excerpt:

\footnotetext{
'It was just historic - the Jones' they made the decisions so there's no point, you [the staff] just do as you're told and that was just an ethos, people didn't create ideas and suggestions, but you have to
} 
make it more of an open workplace... it's quite sad that it takes me until I'm in my mid 50's before I find out who I am.'

Finally, transformative learning or higher level learning (Mezirow 1991) is about re-framing perceptions. Reflection is critical to the process. According to Mezirow (1991) transformative learning 'involves a critique of the presuppositions on which our beliefs have been built' (Mezirow1990, 1). Thus transformative learning has a distinctly personal dimension and can stimulate considerable change in self-understanding (Cope 2003, 437). Seen as a shift in the frames of reference currently accepted by an individual, this is coded in the data as: 'metalearning'. The following participant provides a good illustrative example of the subtle relationship between reflective learning and learning transfer as he compares himself to a senior partner and mentor and reflects on the doubts he had regarding his leadership ability when this person retired:

'I think that's where I started to think oh I'm not quite sure if I can be like him because I've not got the same personality... I was beginning to feel like it wasn't my business and that's not the way I feel now... I identified that I... had all the building blocks of the sort of leader I wanted to be anyway, it was just a question of realising it... [and then a masterclass speaker said] you can't motivate your staff, you can only motivate yourself and how you appear - and it was like an epiphany, because I remember when he described walking into the office head down and not speaking to anyone, I thought that's been me for the last eighteen months and I consciously don't do that from now on, and it's amazing how little things like that can transform how the staff react with you and they will actually come to you again, whereas it had got to the stage where they weren't coming to me even though I am the person they need to come to if they need answers to a problem.' 
The excerpt provides insights into a process of re-emergence that occurred as a consequence of a comment by a masterclass speaker. This prompted significant learning, recognised as important to the business and highly valued by the participant (Waller, 2011), which in turn resulted in the transfer of learning to the business context, as illustrated in the narrative: 'and I consciously don't do that now.'

\section{Social learning}

Social learning is significant in the data and plays a crucial role in learning transfer. Participants appreciated spending time in the company of 'like minded people' in 'similar situations', perhaps seeing themselves as 'comrades in adversity' (Pittaway, Missing, Hudson and Maragh 2013). It is well known that psychological safety is important for group members to feel accepted and respected (Schein and Bennis 1965). It is also recognised as an enabling condition in group dynamics and team learning (Edmondson 1999). This was prominent in the data. Participants emphasised the importance of being able to voice their opinions and discuss business issues openly, honestly, and transparently in a situation where there were 'no expectations' placed on them and the 'boundaries' were removed. Thus we see the emergence of strong learning networks (Pittaway, Missing, Hudson and Maragh 2013). A significant feature is that participants valued the opportunity to share experiences, and to talk about ideas. They benefited by gaining external perspectives from other participants (Hines and Thorpe 1995; Gibb 1997). The data conveys the buzz, excitement, and energy within these learning networks that provided opportunities for the co-construction of learning within the group that individuals could try out in their businesses (Smith 2012). This was supported with other aspects of the programme promoting reflective learning, which spurred participants to take action in their business. This 
created further opportunities for individual learning that was shaped by experience and action. In many instances this also had a cumulative effect on staff:

\footnotetext{
'The fact that I enjoyed the company and the ideas - banter and bouncing all the experiences, and the business life experiences off all the other cohort members has kind of rubbed off on me and rubbed off on my staff. So I've got them doing things now and working their own plan out and I find that releases me from worrying about the day-to-day "putting the cat out" type stuff. So a totally positive experience.'
}

From the data we were able to conclude that social support with learning (Facteau et al. 1995; Tracey, Tannenbaum and Kavanagh 1995) from within a peer group, such as those created by a learning programme, can have important influences, not only on learning, but also on learning transfer to the firm. It was clear, however, that some participants did not benefit as much as others. Some expressed frustration that they were in action learning sets that 'didn't work' or with people who were 'not like minded'. These examples illustrated that some participants experienced some of the disadvantages of action learning; that poor group dynamics can undermine the benefits (McNeill, Lawson and Mulhaney, 2012), particularly when focused on the action learning set component of the programme. Another widespread explanation reflected elsewhere in the literature (McGill and Beaty 2001) is captured succinctly here: 'I think it depends on who you have in there and who was facilitating it as well.'

\section{Emotion and Affective learning}

Following Cope (2010) we explored emotional exposure in terms of financial exposure, relationship risk and social risk. Participants frequently referred to being exposed financially and primarily attributed this to 'the recession', which impacted on them in many ways. For example, 
a participant described 'cataclysmic events' that caused serious financial difficulties in the business. Several participants had closed businesses and at least one 'had taken a liquidation.' Relationship risk was also prominent. In some instances this concerned internal relationships with employees and partners. Some participants faced resistance from business partners or complained of unreasonable demands. Examples of strained external relationships with suppliers, clients, and other stakeholders also appear in the data:

'There's a couple of clients that have just been annoying me for a year or two and just you know they are just so selfish and demanding and I've just told them basically certain things. And some Council people as well who just waste time and I've just been able to explain in quite simple and polite terms where we're up to. And there's an [professional] worker who's constantly letting me down and I've just been to see him and cleared the air.'

Social risk (Cope 2010) also emerged in the data, for instance this person explained: 'it's a small community and they like to see you fail. They thrive on "oh she didn't do well there."' Overall, the data suggests participants were often at great psychological risk, as this person illustrates: '...my behaviour before the LEAD programme, I now treat it as a form of alcoholism or addiction or something.' The most frequent explanation for this is summed up by this person: 'I was tending to be in the middle of all the problems rather than stepping back... running fast and getting nowhere.'

It is, therefore, promising that through the different elements of the programme, participants were encouraged to share their challenges and learn from others. In turn this appears to have had a transformational impact on their state of mind. Cope (2005) highlights that emotional exposure 
can lead to higher levels of learning. Very little is known about how emotions affect learning. From this perspective the data provides some interesting insights. Many participants said they 'enjoyed' the programme and 'fun' elements acted as an important stimulant, although this did not necessarily result in learning. Others talked about the 'comfort' they gained from peers that enabled them to learn and develop as an individual, this aspect would seem to confirm that learning from peers as authentic experts provides emotional support because they understand and appreciate the context within which the entrepreneur operates (Clarke et al. 2006; Pittaway et al. 2009). Frequently the data reveals a sense of energy linked to action learning. The experience was 'very motivational' to the point of giving some participants a 'phenomenal aid and kick' or a 'sense of urgency' to deal with business issues. As this person said, 'LEAD reminded me what it's about, [it was] life changing.' Such data confirms the importance of learner 'motivation' to transfer learning (Blume et al. 2010; Burke and Hutchins 2007; Fraziz, Gittleman and Joyce 2000; Mathieu, Tannenbaum and Salas 1992; Waller 2011, 2012), and illustrates the role of peer pressure in creating a sense of accountability and emotional commitment to carrying out actions (Thorpe et al. 2009). 


\section{Conclusions and implications}

Drawing on data from 19 focus groups involving 51 participants undertaken over a two year period the paper presents findings on learning transfer from the LEAD Wales programme and factors affecting it, arguing that entrepreneurs must engage in 'action' in order to 'learn' and then they may transfer what they have learnt to the firm. Action learning has been typically framed as a critical, reflexive process which focuses on the learning development of the individual. Previous literature has begun to point to the possibility that individual participation in action learning might lead to wider organisational impact through a process of learning transfer, and this paper has found some support for this. However there is no guarantee that organisational learning transfer follows from action learning - indeed for some participants in the present study this connection was not strong. Nevertheless, within the context of the LEAD Wales programme the findings show that action learning can create an arena for the co-construction of learning that entrepreneurs can try out and experiment with in their business (Smith 2012), thus creating further opportunities for learning that is shaped by experience and action. With support from peers action learning creates significant opportunities for entrepreneurs to engage in critical reflection both individually and collectively, to explore business issues, to consider the previously unconsidered, and to reflect on their experiences and those of their peers. Our findings confirm key themes in the learning transfer literature. Consideration of participants' personal learning tendencies and motivations, of programme design and of the culture of the workplace are all critical (Baldwin and Ford, 1988; Holton 1996; Yanmill and McLean 2001). However, programme design has a central role to play. It is argued here that action learning is a method of facilitating entrepreneurial learning able to solve the problems of engagement, relevance and value (Clarke et al. 2006; Pittaway et al. 2009; Pittaway and Thorpe 2012), 
recognised as critical to learning transfer (Waller 2011, 2012). The paper has highlighted factors that facilitate and hinder this process for practitioners that may want to adopt action learning in other entrepreneurial programmes.

In conclusion the efficacy of an entrepreneurial learning intervention in SMEs may depend on the effectiveness of learning transfer and we have identified learning activities required to yield successful actions and outcomes. Additional research, however, would be of value to further explore these complex mechanisms. Greater understanding of the range of transfer types (what) and the methods (how) has implications for successful design of entrepreneurial leadership programmes, with broader implications for national educational policy.

\section{References}

Abell, D. 1978. "Strategic Windows." Journal of Marketing 42 (3): 21-26. doi:10.2307/1250529.

Anderson, V. and Skinner, D. 1999. "Organizational learning in practice: How do small businesses learn to operate internationally?" Human Resource Development International 2 (3): 235-258. doi: 10.1080/13678869900000025.

Armstrong, D., A. Gosling, J.Weinman, and T. Marteau. 1997. "The Place of Inter-Rater Reliability in Qualitative Research: An Empirical Study.” Sociology 31 (3): 597-606. doi: $10.1177 / 0038038597031003015$.

Baldwin, T. T, and Ford, J. K. 1988. "Transfer of Training: A review of the literature and directions for future research." Personnel Psychology 41: 63-105. doi: 0.1111/j.17446570.1988.tb00632.x. 
Bandura, A. 1977. Social Learning Theory, Englewood Cliffs: Prentice Hall.

Bandura, A. 1986. Social Foundations of Thought and Action: A Social Cognitive Theory, Englewood Cliffs, NJ: Prentice Hall.

Baker, M., Andriessen, J. and Järvelä S. 2013. "Affective Learning Together: Social and emotional dimensions of collaborative learning (New Perspectives on Learning)." Abington, Oxon: Routledge.

Bloor, M., S. Frankland, M.Thomas, and K. Robson. 2001. "Focus Groups in Social Research." London: Sage.

Blume, B. D., Ford, J. K., Baldwin, T. T. and Huang, J. L. 2010. "Transfer of training: a metaanalytic review." Journal of Management 39: 1065-105. doi: 10.1177/0149206309352880.

Boud, D., R. Keogh, and D. Walker. 1985. "What is Reflection in Learning?" In Using Experience for Learning, edited by D. Boud, R. Keogh, and D. Walker, 7-17. London: Kogan.

Boyatzis, R. 1998. Transforming Qualitative Information: Thematic Analysis and Code Development, Thousand Oaks, CA: Sage.

Broad, M. L. 1997. "Transfer Concepts and Research Overview." Chap. 1 in Transferring Learning to the Workplace, edited by Jack J Phillips. Alexandria, VA: American Society for Training and Development.

Bryman, A. 2004. Social Research Methods. New York: Oxford University Press Inc. 
Burke, L. A. and Hutchins, H. M. 2007. "Training transfer: an integrative literature review", Human Resource Development Review 6: 263-96. doi: 10.1177/1534484307303035.

Cho, Y., and Egan, T. M. 2009. "Action Learning Research: A Systematic Review and Conceptual Framework." Human Resource Development 8 (4): 431-462. doi: $10.1177 / 1534484309345656$.

Clarke, J., R. Thorpe, L. Anderson, and J. Gold. 2006. "It's all Action, it's all Learning: action learning in SMEs." Journal of European Industrial Training 30 (6): 441-455. doi: $10.1108 / 03090590610688825$.

Colquitt, J. A., Lepine, J. A. and Noe, R. A. 2000. "Toward and integrative of training motivation: A meta-analytic path analysis of 20 years of research." Journal of Applied Psychology 85: 678-707. doi: 10.1037/0021-9010.85.5.678.

Cope, J. 2003. "Entrepreneurial Learning and Critical Reflection: Discontinuous events as triggers for 'higher-level' learning." Management Learning 34 (4): 429-450. doi: $10.1177 / 1350507603039067$.

Cope, J. 2005. "Toward a Dynamic Learning Perspective of Entrepreneurship." Entrepreneurship Theory and Practice 29 (4): 373-397. doi: 10.1111/j.15406520.2005.00090.x.

Cope, J. 2010. "Entrepreneurial Learning from Failure: An interpretative phenomenological analysis.” Journal of Business Venturing 26 (6): 604-623. doi: 10.1016/j.jbusvent.2010.06.002. 
Cope, J. and G. Watts. 2000. "Learning by Doing: an exploration of experience, critical incidents and reflection in entrepreneurial learning." International Journal of Entrepreneurial Behaviour and Research 6(3): 104-124. doi: 10.1108/13552550010346208.

Cuncliffe, A. L. 2004. "On Becoming a Reflexive Practitioner." Journal of Management Education 28 (4): 407-426. doi:10.1177/1052562904264440.

Dalley, J. and Hamilton, B. 2000. "Knowledge, context and learning in the small business." International Small Business Journal 18 (3), 51-59. doi: 10.1177/0266242600183003

Deakins, D. 1996. Entrepreneurship and Small Firms. London: McGraw-Hill.

Deakins, D. and M. Freel. 1998. "Entrepreneurial Learning and the Growth Process in SMEs." The Learning Organisation 5 (3): 144-155. doi:10.1108/09696479810223428.

De-Fillipi, R. J. 2001. "Introduction: Project-based Learning, Reflective Practices and Learning Outcomes." Management Learning 32 (1): 5-10. doi: 10.1177/1350507601321001.

Detteman, D. K. 1993. “The Case for Prosecution: Transfer and Epiphenomenona." In Transfer on Trial: Intelligence, Cognition and Instruction Norwood, edited by D. K. Detterman and R. J. Sternberg, 1-23. NJ: Ablex.

Devins, D. and J. Gold. 2000. "Cracking the Tough Nuts: mentoring and coaching the managers of small firms." Career Development International 5 (4): 250-255. doi: 10.1108/EUM0000000005363.

Edmondson A.C. 1999. "Psychological Safety and Learning Behaviour in Work Teams". Administrative Science Quarterly 44 (2): 350 -383. doi: 10.2307/2666999. 
Facteau, J. D., Dobbins, G. H., Russell, J. E. A., Ladd, R. T., and Kudishch, J. D. 1995. “The Influence of General Perceptions of the Training Environment on Pretraining Motivation and Perceived Training Transfer." Journal of Management 21: 1-25. doi: 10.1177/014920639502100101.

Foley, J. M. and Kaiser, L. M. R. 2013. "Learning Transfer and Its Intentionality in Adult and Continuing Education." New Directions for Adult and Continuing Education 137: 5-15. doi: 10.1002/ace.20040.

Fraziz, H., Gittleman, M. and Joyce, M. 2000. "Correlates of Training: an analysis using both employer and employee characteristics." Industrial and Labour Relations Review 53, 443462.Stable URL: http://www.jstor.org/stable/2695968.

Gartner, W. B., Bird, B. J., and Starr, J. A. 1992. "Acting as if: Differentiating Entrepreneurial from Organizational Behaviour.” Entrepreneurship Theory and Practice 16 (3): 13-32.

Gibb, A. 1997. 'Small Firms' Training and Competitiveness. Building upon Small business as a Learning Organisation." International Small Business Journal 15 (3): 13-29. doi: $10.1177 / 0266242697153001$.

Gibb, A. 2002. "In pursuit of a New 'Enterprise' and 'Entrepreneurship' Paradigm for Learning: creative destruction, new values, new ways of doing things and new combinations of knowledge." International Journal of Management Reviews 4 (3): 233-269. doi:10.1111/1468-2370.00086. 
Gibb, A. 2009. "Meeting the Development needs of Owner Managed Small Enterprise: a discussion of the centrality of action learning." Action Learning: Research and Practice 6 (3): 209-227. doi: 10.1080/14767330903299415.

Gibb, A. and J. Ritchie. 1982. "Understanding the Process of starting Small businesses." European Small Business Journal 1(1): 26-45. doi: 10.1177/026624268200100102.

Gilpin-Jackson Y. and Bushe, G.R. 2007. "Leadership development training transfer: a case study of post-training determinants." Journal of Management Development 26(10): 9801002. doi: $10.1108 / 02621710710833423$.

Gold, J. and Thorpe, R. 2010. "Leadership and Management Development in Small and Medium-Sized Enterprises: SME Worlds." In Gower Handbook of Leadership and Management Development, edited by Gold, J., Thorpe, R. and A. Mumford, Chap. 8, 133150. Surrey: Gower Publishing Limited.

Henley, A. and H. Norbury. 2011. "An Intervention in raise Leadership Effectiveness among SME Owner-managers in Wales.” Entrepreneurship and Innovation 12 (4): 221-233. doi: 10.5367/ijei.2011.0048.

Harvey, M. and R. Evans.1995. "Strategic Windows in the Entrepreneurial Process." Journal of Business Venturing 10 (5): 331-347. doi: 10.1016/0883-9026(95)00037-9

Hicks, M. D., and Peterson, D. E. 1999. "The development pipeline: How people really learn.” Knowledge Management Review 9: 30-33. 
Hines, T., and R. Thorpe. 1995. "New Approaches to Understanding Small firm Networks - the key to performance, managerial learning and development." Paper presented at the 18th ISBA National Small Firms Policy and Research Conference, Paisley, November15-17.

Holman, D., Pavlica, K., and Thorpe, R. 1997. "Rethinking Kolb's theory of experiential learning in management education.” Management Learning 28 (2): 135-148. doi: $10.1177 / 1350507697282003$.

Holton, E.F. III. 1996. "The flawed four-level evaluation model." Human Resource Development Quarterly 7 (1): 5-21. doi: 10.1002/hrdq.3920070103.

Inglis, S. 1994. “Making the Most of Action Learning." Hampshire: Gower.

Ingram, H., Biermann, J., Cannon, J., Neil. J. and Waddle, C. 2000. "Internalising Action Learning: a company perspective.” International Journal of Hospitality Management, 12 (2): 107-114. doi: 10.1108/09596110010307369.

Johnson, C. 1998. “The Essential principles of Action Learning.” Journal of Workplace Learning 10 (6/7): 296-300. doi: 10.1108/13665629810236219.

Jones, O., A. Macpherson, and R.Thorpe. 2010. "Learning in Owner-managed Small firms: mediating artefacts and strategic space." Entrepreneurship and Regional Development 22 (7): 649-673. doi: 10.1080/08985620903171368. 
Jones, K., A. Henley, S. Sambrook, and H. Norbury. 2013. "Learning to LEAD for Business Growth - Implications for Supporting SMEs in Wales." Contemporary Wales, 26, 1-23. ISBN: 978-0-7083-2683-1.

Kempster, S. 2009. How Managers Have Learned to LEAD: Exploring the Development of Leadership Practice. London: Palgrave Macmillian.

Kempster, S., J. Cope, and K. Parry. 2010. "Dimensions of distributed leadership in the SME context." Working Paper 10-01. Glasgow: Hunter Centre for Entrepreneurship and University of Strathclyde.

Kempster, S., and G. Watts. 2002. "The Entrepreneur as Leader: an exploration of leadership development amongst small business owner managers." Paper presented at the $25^{\text {th }}$ ISBA National Small Firms Conference, Brighton, November 13-15.

Kerr, R., J. Gavin, N. Heaton, and E. Boyle. 2005. "Emotional Intelligence and Leadership Effectiveness", Leadership and Organization Development Journal 27 (4): 265-279. doi: 10.1108/01437730610666028.

Kirwan, C. 2009. Improving Learning Transfer. Farnham: Gower Publishing Limited.

Kitzinger, J. 1994. "The Methodology of Focus Groups: the importance of interaction between research participants." Sociology of Health and Illness 16 (1): 103-21. doi: 10.1111/14679566.ep11347023.

Kraiger, K. 2003. "Perspectives on Training and Development. Handbook of Psychology." Industrial and Organizational Psychology 1: 171-92. doi: 10. 1002/0471264385.wei1208. 
Leonard, H. K., and Lang, F. 2010. “Action Learning for Leadership Development.” Advances in Human Resources 12(2) 225-240. doi: 10.1177/1523422310367800.

Leitch, C.M., and R.T. Harrison. 2005. "Entrepreneurial Learning: researching the interface between learning and the entrepreneurial context." Entrepreneurship Theory and Practice 9 (2): 351-71. doi: 10.1111/j.1540-6520.2005.00089.x.

Leitch, C. M., C. McMullan, and R. T. Harrison. 2009. "Leadership Development in SMEs: an action learning approach." Action Learning: Research and Practice 6 (3): 243-263. doi: 10.1080/14767330903299464.

Lincoln, Y.S., and E.G. Guba .1985. Naturalistic Inquiry. London: Sage Publications, Inc.

Martin, P.Y. and B. Turner.1986. "Grounded Theory and Organizational Research.” The Journal of Applied Behavioural Science 22 (2): 141-157. doi: 10.1177/002188638602200207.

Mathieu, J. E., Tannenbaum, S. I. and Salas,E. 1992. "Influences of Individual and Situational Characteristics on Measures of Training Effectiveness." Academy of Management Journal 35, 4, 828-847. doi: 10.2307/256317.

Merriam, S. B. and Leahy, B. L. 2005. "Learning Transfer: a review of the research in adult education and training." PAACE Journal of Lifelong Learning 14: 1-24.

McGill I. and Beaty, L. 2001. Action Learning. London and New York: RoutledgeFalmer.

McNeill, T., Lawson, J. and Mulhaney, A. 2012. "SME Learning Sets - What do Participants Value in One Another?" Paper presented at the $35^{\text {th }}$ Annual Institute of Small Business and Entrepreneurship (ISBE) Conference, Dublin, November 2012. 
Mezirow, J. 1990. Fostering Critical Reflection in Adulthood. San Francisco: Jossey Bass.

Mezirow, J. 1991. Transformative Dimensions of Adult Learning. San Francisco: Jossey Bass.

Minniti, M. and W. Bygrave. 2001. "A Dynamic Model of Entrepreneurial Learning." Entrepreneurship Theory and Practice 25(3): 5-16. doi: 1042-2587-01-251.

Pedler, M. 1997. "Interpreting Action Learning." In Management Learning; Integrating Perspectives in Theory and Practice, edited by J.Burgoyne and M.Reynolds 248-264. Sage: London.

Pedler, M. 2008. Action Learning for Managers, Padstow, Cornwall: TJ International Ltd.

Penn, D.W., Ang'wa, W., Forster, R., Heydon, G., and Richardson, S.J. 1998. "Learning in smaller organizations." The Learning Organisation 5(3), 128-137. doi: $10.1108 / 09696479810223400$

Perren, L. and Grant, J. 2001. "Management and Leadership in UK SMEs." London: Council for Excellence in Management and Leadership.

Peters, S. 2010. "Where does the learning take place? Learning spaces in the situated curriculum within networked learning." Edited by L. Dirckinck-Holmfeld, V. Hodgson, C. Jones, M. de Laat, D. McConnell, and T. Ryberg. Paper presented at the $7^{\text {th }}$ International Conference on Networked Learning, Aalborg, Denmark, May 3-4.

Pittaway, L. and J. Cope. 2007. "Simulating Entrepreneurial Learning: Assessing the Utility of Experiential Learning Designs.” Management Learning. 38 (2): 211-233. doi: 10.1177/1350507607075776. 
Pittaway, L., C. Missing, N. Hudson, and D. Maragh. 2009. "Entrepreneurial Learning through Action: A case study of the six-squared program." Action Learning: Research and Practice 6 (3): 265-88. doi: 10.1080/14767330903299480.

Pittaway, L., and R. Thorpe. 2012. “A Framework for Entrepreneurial Learning: A tribute to Jason Cope." Entrepreneurship and Regional Development 24 (9-10): 837-859. doi: 10.1080/08985626.2012.694268.

Ram, M., and K. Trehan. 2010. "Critical Action Learning, Policy, Small Firms and Learning: an inquiry." Management Learning 41(4): 415-428. doi: 10.1177/1350507609349155.

Rae, D. 2000. "Understanding Entrepreneurial Learning: A question of how?" International Journal of Entrepreneurial Behaviour and Research 6 (3): 145-159. doi: $10.1108 / 13552550010346497$.

Rae, D., and M. Carswell. 2001. "Towards a Conceptual Understanding of Entrepreneurial Learning." Journal of Small Business and Enterprise Development 8 (2):150-158. doi: 10.1108/EUM0000000006816.

Reuber, A.R. and E.M. Fischer. 1999. "Understanding the Consequence of Founders' Experience.” Journal of Small Business Management 37 (2): 30-45. Available at SSRN: http://ssrn.com/abstract=1505887.

Revans, R. W. 1980. Action Learning: New Techniques for Management. London: Blond and Briggs. 
Revans, R.W. 1993. “Action Learning; its terms and character.” Management Decision 21 (1): 39-50. doi: 10.1108/eb001310.

Reynolds, M. 2011. "Reflective Practice: origins and Interpretations.” Action Learning, Research and Practice 8 (1): 5-13. doi: 10.1080/14767333.2011.549321.

Rigg, C. 2005. "It's in the way they talk." International Journal of Entrepreneurial Behaviour and Research 11 (1): 58-75. doi: 10.1108/13552550510580843.

Rigg, C., and Trehan, K. 2002. "Do they or don't they? A Comparison of Traditional and Discourse Perspectives in HRD in SMEs.” Education and Training 44, (8/9): 388-397. doi: 10.1108/00400910210449222.

Rouiller, J. Z. and Goldstein, I. L. 1993. "The relationship between organizational transfer climate and positive transfer of training." Human Resources Development Quarterly 4, 377-90. doi: 10.1002/hrdq.3920040408.

Saks, A. M. and Belcourt, M. 2006. "An investigation of training activities and transfer of training in organisations." Human Resource Management 45, 629-48. doi: 10.1002/hrm.20135.

Schein, E.H. and W. Bennis. 1965. Personal and Organizational Change through Group Methods. New York: Wiley.

Sexton, D.L., N.B. Upton, L.E. Wacholtz, and P.P. McDougall. 1997. "Learning needs of Growth-oriented Entrepreneurs." Journal of Business Venturing 12(1): 1-8. doi: 10.1016/S0883-9026(96)00037-7. 
Smilor, R.W. 1997. "Entrepreneurship: Reflections on a Subversive Activity." Journal of Business Venturing 12(5): 341-346. doi: 10.1016/S0883-9026(97)00008-6.

Smith, L. and Peters, S. 2006. Leading by Design: The case of LEAD. Paper presented at Symposium Entrepreneurial Leadership Learning, British Academy Management, Belfast, September 12-14.

Smith, S. 2011. "SME leaders' learning in networked learning: an actor-network theory and communities of practice theory-informed analysis." Unpublished PhD thesis, University of Lancaster.

Smith, S. 2012. "Reconceptualising Space in Networked Learning." Proceedings of the 8th International Conference on Networked Learning, 2-4 April 2012. Edited by V. Hodgson, C. Jones, M. de Laat, D. McConnell, T. Ryberg, and P. Sloep. ISBN 978-1-86220-283-2.

Stanworth, J. and C. Gray, 1991. Bolton 20 years on: The Small Firm in the 1990s. London: Small Business Research Trust.

Stewart, J.A. 2009. "Evaluation of an Action Learning Programme for Leadership Development of SME Leaders in the UK." Action Learning: Research and Practice 6 (2): 131-148. doi: $10.1080 / 14767330903006802$.

Storey, D.J. 1994. Understanding the Small Business Sector. London: International Thomson Business Press.

Tannenbaum, S. I. and Yulk, G. 1992. "Training and Development in Work Organisations." Annual Review of Psychology 43: 399-441. doi: 10.1146/annurev.ps.43.020192.002151. 
Taylor, D. W. and R. Thorpe. 2004. "Entrepreneurial Learning: a process of co-participation." Journal of Small Business and Enterprise Development 11(2): 203-211. doi: $10.1108 / 14626000410537146$.

Tell, J. 2000. "Learning Networks - a metaphor for inter-organizational development in SMEs", Enterprise and Innovation Management Studies 1 (3): 303-317. doi: $10.1080 / 14632440010028302$.

Thomson, A., J. Storey, C. Mabey, C. Gray, E. Farmer, and R. Thomson. 1997. A Portrait of Management Development. London: Institute of Management/Open University.

Thorpe, R., J. Cope, M. Ram, and M. Pedler. 2009. "Leadership Development in Small and Medium-sized Enterprises: The case for action learning." Action Learning: Research and Practice 6 (3): 201-8. doi: 10.1080/14767330903299399.

Tracey, J. Bruce; Tannenbaum, Scott I.; Kavanagh, Michael J. 2005. “Applying trained skills on the job: The importance of the work environment." Journal of Applied Psychology 80, 2, 239-252. doi: $10.1037 / 0021-9010.80 .2 .239$.

Velada, R., Caetano, A., Michel, J. W. Lyons, B. D. and Kavanagh, M. J. 2007. "The effects of training design, individual characteristics and work environment on transfer of training." International Journal of Training and Development 11, 282-94. doi: 10.1111/j.14682419.2007.00286.x.

Vince, R. (2008) “'Learning in-action and 'Learning inaction': advancing the theory and practice of critical action learning", Action Learning Research and Practice, 5 (2): 93-104. 
Waddill, D. and Marquardt, M. (2011) “Adult Learning Theories and the Practice of Action Learning' in Action Learning in Practice” edited by Mike Pedler, 415-427,Surrey: Gower.

Waller, L. (2011) From the Classroom to the Workplace: enhancing the transfer of learning. Berkhamsted: Ashridge Business School.

Waller, L. 2012. From the Classroom to the Workplace: enhancing the transfer of learning. Hertfordshire: Ashridge Business School.

Westhead, P. and D. Storey. 1996. "Management Training and Small firm Performance: why is the link so weak?" International Small Business Journal 14 (4): 13-24. doi: 10.1177/0266242696144001.

Wilkinson, S. 1998. "Focus Groups in Feminist Research: Power, Interaction, and the CoProduction of Meaning." Women's Studies International Forum 21 (1): 111-25. doi: 10.1016/S0277-5395(97)00080-0.

Wilkinson, S. J. 1999. “Focus groups: A Feminist Method.” Psychology of Women Quarterly 23 (2): 221-244. doi: 10.1111/j.1471-6402.1999.tb00355.x.

Woo, C.V., U. Daellenbach, and C. Nicholls-Nixon. 1994. "Theory Building in the Presence of "Randomness": the case of venture creation and performance." Journal of Management Studies 31(4): 507-524. doi: 10.1111/j.1467-6486.1994.tb00628.x.

Yanmill, S. and G. N. McLean. 2001. "Theories supporting transfer of learning." Human Resource Development Quarterly 12(2): 195-208. doi: DOI: 10.1002/hrdq.7. 
Yin, R.K. 1989. Case Study Research - Design and Methods. Newbury Park, CA: Sage Publications. 
Appendix 1. Explanation and examples of second level thematic coding

\begin{tabular}{|c|c|c|c|}
\hline $\begin{array}{l}\text { Second Level Thematic } \\
\text { Coding }\end{array}$ & $\mathbf{N}$ & $\begin{array}{r}\text { Per } \\
\text { Cent } \\
\end{array}$ & Explanation with examples from the data \\
\hline \multicolumn{4}{|l|}{$1 \quad$ Learning by doing } \\
\hline \multicolumn{4}{|c|}{ 1.1 Randomness, experimentation and dynamic aspects } \\
\hline $\begin{array}{l}\text { Putting into action in the } \\
\text { business }\end{array}$ & 125 & 40 & $\begin{array}{l}\text { This category captures transfer of ideas into action in the business. Prominent themes concern: 1) Strategy and } \\
\text { business growth: I'm doing a hell of a lot more strategically; bought part of a new business; expanded; } \\
\text { [diversified] into another business). 2) Financial management: changed accountant; negotiated with bank; } \\
\text { getting quotes [to reduce overheads]; instigated purchase orders. 3) Organisation and structure: structured } \\
\text { management meetings; separate departmental meetings; structure and planning... organisational charts and } \\
\text { people have [clear] responsibilities; set targets and monitoring them; restructured roles. 4) IT, marketing and } \\
\text { PR: [got] promotion leaflets, and rearranged my cards, my website's up to scratch; online bookings; change } \\
\text { the way we sell ourselves; changed logo; branding; professionalism; formal networking; promoted the } \\
\text { business on radio and television. }\end{array}$ \\
\hline $\begin{array}{l}\text { Experimenting with } \\
\text { leadership styles }\end{array}$ & 159 & 51 & $\begin{array}{l}\text { Leadership learning transferred to the business broadly incorporates themes concerned with: 1) Leadership } \\
\text { style: empowering; delegating work and sharing more; I'm involving [staff] more... get their opinions; I'll } \\
\text { ask them 'how do you think we should approach this?' 2) Assertiveness: first thing I did was sack one guy } \\
\text { when I got back... a lot of stress disappeared; far less tolerant of people not doing their jobs; challenge ideas; } \\
\text { proactive having [difficult] conversations. 3) Nurturing values based culture: build up an organisation that is } \\
\text { built around mutual trust; develop a positive working culture. 4) Charisma: harnessed a possibly nicer way of } \\
\text { doing what I did before; change my character quite a bit; I've actually opened up a lot; more diplomatic. }\end{array}$ \\
\hline Non-transfer & 26 & 8 & $\begin{array}{l}\text { Prominent themes concerning non-transfer include: 1) Procrastination: I don't think it's good to implement } \\
\text { too many fresh ideas too quickly; I haven't really gone back and done any of those specific exercises; it's just } \\
\text { a question of doing it really. 2) Lack of relevance/practical application: not in the slightest bit relevant to } \\
\text { where I am at; I think a little bit more time [is needed to look at] how have you applied it; it falls off the cliff } \\
\text { a little bit when, ok how do we take that back into our business? }\end{array}$ \\
\hline \multicolumn{4}{|l|}{ 1.2 Learning tasks } \\
\hline Learning about self & 46 & 21 & $\begin{array}{l}\text { Examples of this code include: understanding me; making me think about how I did think and about how I felt } \\
\text { about things; I've learned that I'm not a leader. I'm a manager and that's what I've got to work on; I realised I } \\
\text { had some issues; [learnt] what people perceived about me and what I thought about myself. }\end{array}$ \\
\hline Learning about business & 63 & 29 & $\begin{array}{l}\text { This code include: 1) Learning applicable to the business: I was picking relevant points from each } \\
\text { [Masterclass]; I've never been to a marketing class in my life...so, it gave me an insight into the sorts of } \\
\text { things; learnt a lot from [sales Masterclass]. 2) Learning about the business itself: understand better the } \\
\text { direction of the firm and how to achieve it. }\end{array}$ \\
\hline $\begin{array}{l}\text { Learning about leadership and } \\
\text { management of employees }\end{array}$ & 77 & 35 & $\begin{array}{l}\text { This code includes: 1) Explicit reference to learning: made me understand the employees better... and the } \\
\text { contribution they can or they can't make to the firm. 2) Illustrative examples of learning: to get the most out } \\
\text { of the office manager I need to recognise what he's good at and concentrate what he is good at. }\end{array}$ \\
\hline $\begin{array}{l}\text { Learning about the business } \\
\text { context }\end{array}$ & 7 & 3 & $\begin{array}{l}\text { Although there is a general sense that participants gained a greater awareness of the wider business context, } \\
\text { few explicit examples exist of this code. This excerpt provides an example: I think we already know that we } \\
\text { were flogging a dead horse... we were never going to achieve that [attracting high value city clients in a small }\end{array}$ \\
\hline
\end{tabular}




\begin{tabular}{|c|c|c|c|}
\hline & & & rural area] \\
\hline $\begin{array}{l}\text { Learning about the } \\
\text { management of external } \\
\text { relations }\end{array}$ & 20 & 9 & $\begin{array}{l}\text { There are clear examples of this code in the data: [in a heated meeting] just realised the best thing to do is just } \\
\text { stay quiet, say thank you very much, walk out; clients I'm working with... when I see politics creeping in I'll } \\
\text { just ask them to take a step back and 'can we just think about that for a little bit longer'; portraying your } \\
\text { business to the bank or to a client or to a financier or whatever... that is really really important. }\end{array}$ \\
\hline Non-transfer of learning & 7 & 3 & $\begin{array}{l}\text { A minority were unable to transfer learning as it was not relevant. This is captured in this code, for example: it } \\
\text { would be better to have something to do then after that is relevant to our business; I don't think there's any } \\
\text { real business input. }\end{array}$ \\
\hline \multicolumn{4}{|l|}{ 1.3 Preparedness to act } \\
\hline Increased confidence & 73 & 51 & $\begin{array}{l}\text { Although the coding shows } 73 \text { themes concerning 'confidence', the term appears } 128 \text { times in the transcripts. } \\
\text { This is a clear theme with participants consistently articulating gains in confidence, expressed in terms such } \\
\text { as: My confidence has definitely grown on it; more of a confidence booster to me more than anything; huge } \\
\text { confidence boost. }\end{array}$ \\
\hline $\begin{array}{l}\text { Motivation to seek new } \\
\text { opportunities }\end{array}$ & 69 & 49 & $\begin{array}{l}\text { Related to increased confidence, the next code concerns increased motivation to seek out new opportunities: } \\
\text { whoof sort of reasserted myself and it's given me a line now where I want to go for the next sort of four or } \\
\text { five years; I can see now that there are opportunities for those that want them; I've been going around } \\
\text { thinking 'what shall I do, I need to do something'; I'm continuously thinking now well I wonder if I can?... } \\
\text { thinking 'oh I'll open a school!' }\end{array}$ \\
\hline \multicolumn{4}{|c|}{ 1.4 Outcomes from experiences may be intended or unintended } \\
\hline Social context & 29 & 11 & $\begin{array}{l}\text { Themes include: 1) Social contexts within the business: management morale is much better; well-motivated } \\
\text { staff and 2) Externally: better relationships with local health boards; business networks have become opened } \\
\text { more [in the town]. }\end{array}$ \\
\hline $\begin{array}{l}\text { Unexpected changes in self, } \\
\text { leadership, staff/partnerships }\end{array}$ & 168 & 63 & $\begin{array}{l}\text { This is a broad code, hence the number of instances noted. It includes: 1) Unexpected changes in self: it has } \\
\text { changed me; come out of my shell; refocused the mind; wake up excited about the business; 2) Leadership: it } \\
\text { just means so much when you motivate people; helped me to actually carry things through and make } \\
\text { decisions; 3) Unexpected changes in staff and partnerships: staff realise this is a proper business finally; being } \\
\text { taken more seriously; totally different relationship with business partner. }\end{array}$ \\
\hline $\begin{array}{l}\text { Possible outcomes in the } \\
\text { business }\end{array}$ & 60 & 23 & $\begin{array}{l}\text { Examples of this code include: push the business forward in a different direction; we've gone from } 25-27 \\
\text { people and we're now up to } 45 \text {; we are putting work out the door like there's no tomorrow, really going } \\
\text { strong. }\end{array}$ \\
\hline $\begin{array}{l}\text { Unexpected negative } \\
\text { outcomes }\end{array}$ & 8 & 3 & $\begin{array}{l}\text { This code includes: 1) Negative outcomes transferring learning to the business: I'm trying to talk to my staff } \\
\text { who've had no experience of it, no exposure and they think I'm an alien; staff morale has seemed to have } \\
\text { gone; these guys are not tooled up to move with you. 2) Negative outcomes as a consequence of participation } \\
\text { in LEAD: there isn't a formal structure for me to come to now; I'm on my own now in a sense; it's added } \\
\text { more confusion for me; you're stuck with all this knowledge this academic practical knowledge but how do I } \\
\text { put it into practice? }\end{array}$ \\
\hline \multicolumn{4}{|l|}{ 2. $\quad$ Reflective learning } \\
\hline $\begin{array}{l}\text { Observations of self in the } \\
\text { context of action }\end{array}$ & 138 & 45 & $\begin{array}{l}\text { Although difficult to illustrate succinctly, the following excerpts provide examples of this code: I don't really } \\
\text { seem to set aside enough time to reflect on what is happening in the business; I was doing a lot of fire } \\
\text { fighting; I can't continue doing what I did before. }\end{array}$ \\
\hline
\end{tabular}




\begin{tabular}{|c|c|c|c|}
\hline $\begin{array}{l}\text { Observations of self in } \\
\text { relation to others }\end{array}$ & 50 & 16 & $\begin{array}{l}\text { Themes within this code primarily concern observations of self in relation to other programme participants } \\
\text { and staff: I often wonder what are my staff thinking; I always thought everybody else was better than me; at } \\
\text { the end of the day it's given me a kind of - oh I'm better than him; cor is that how I'm perceived? This code } \\
\text { also includes observations of self in relation to business partners and notable people. }\end{array}$ \\
\hline Changes in self-perception & 69 & 23 & $\begin{array}{l}\text { This is a prominent code within the reflective practice category. Most prominently changes in self-perception } \\
\text { concern leadership: I can actually do it; We're becoming, we haven't become yet but we are becoming } \\
\text { [leaders]; I didn't feel like I was a leader to be honest with you, not before, but now I expect I do; I do feel } \\
\text { I'm a better person in the business; I'm sort of shifting my view. I always thought of myself as an instructor } \\
\text { and I'm shifting that now to more of a manager. }\end{array}$ \\
\hline Meta-learning & 43 & 14 & $\begin{array}{l}\text { Meta learning is difficult to capture and represent in short excerpts, however the following provide an } \\
\text { illustration of this code: stand back and see the bigger picture to be a part of the bigger picture; it made me } \\
\text { think differently - full stop; it was a time that made sense to me... it certainly clicked at that stage; life } \\
\text { changing; this made me realise there was something else out there; enabled me to grow as an individual. }\end{array}$ \\
\hline Non-learning & 5 & 2 & $\begin{array}{l}\text { A small number of participants felt opportunities for reflective learning were not fully utilized, this is captured } \\
\text { in this code: not enough opportunities to actually reflect on what we've actually done; I would have liked } \\
\text { more time to reflect on the morning session; More reflecting time [needed]. }\end{array}$ \\
\hline \multicolumn{4}{|l|}{ 3. Social Learning } \\
\hline Antecedents & 58 & 19 & $\begin{array}{l}\text { This code identified antecedents to social learning that give participants: 1) A sense of Sense of belonging: } \\
\text { like-minded people; like-minded situations; similar issues; similar direction; share the same problems and key } \\
\text { values; great group of people; gel as a team; community spirit. 2) Psychological safety: voice opinions; } \\
\text { support; enthusiasm; High level of trust; open; honest; transparency; no expectations on you; ask questions; } \\
\text { drop boundaries; working together. }\end{array}$ \\
\hline Sharing experiences & 75 & 25 & $\begin{array}{l}\text { Illustrative examples of themes in this code include aspects of the experience concerned with social } \\
\text { interaction and engagement: a lot of positive talking... no negative; finding... it's not just you that's stressed } \\
\text { out; helping and making a difference; listening to people; discuss openly; extreme discussion; [express and } \\
\text { gain] ideas. }\end{array}$ \\
\hline Learning from others & 61 & 20 & $\begin{array}{l}\text { This code includes learning through: 1) Observation: the experience of going into another business... there's } \\
\text { such a lot that you gain from it; being with different people... you see how they're making money; helped me } \\
\text { to understand somebody else's [business] and for them to come and give me some ideas as well, and we're } \\
\text { still working together. 2) Gaining external perspectives an honest opinion; getting around those people and } \\
\text { being influenced, and gathering information on how they did it. It just saves ten years of agro to just jump } \\
\text { ahead. }\end{array}$ \\
\hline Resistance to expose self & 3 & 1 & $\begin{array}{l}\text { The coding identified some reluctance to engage in social learning, for example: some people deliberately } \\
\text { made up that they had a problem; I don't think I had any problems to discuss; I wasn't particularly } \\
\text { comfortable networking. }\end{array}$ \\
\hline $\begin{array}{l}\text { Seeking consensus and } \\
\text { involving staff before taking } \\
\text { ideas forward }\end{array}$ & 23 & 8 & $\begin{array}{l}\text { This code overlaps with code one (Randomness, experimentation and dynamic aspects), which incorporates } \\
\text { experimentation with leadership style. Nevertheless, we wanted to show how some participants gain } \\
\text { consensus and involve staff, for example: there is a request out there for their input; we do talk more about } \\
\text { business not just me thinking about it; open to suggestions from them as well about how it might be done; } \\
\text { staff sort out their work and challenges; as a team we create actions and divide them among the staff; Sent }\end{array}$ \\
\hline
\end{tabular}




\begin{tabular}{|c|c|c|c|}
\hline & & & $\begin{array}{l}\text { email to staff saying, 'as you know I've been to LEAD, we had a Masterclass on this and one of the things } \\
\text { mentioned was this... What does everybody think about implementing that in the business.' And then got } \\
\text { feedback. }\end{array}$ \\
\hline $\begin{array}{l}\text { Transfer of learning to staff } \\
\text { and/or partners }\end{array}$ & 41 & 14 & $\begin{array}{l}\text { This code concerns: 1) Sharing learning with staff: I've fed back...; I debriefed our guys after every time we } \\
\text { met; passing the information on to the staff. 2) Learning style: I developed the shadowing [in the business]; } \\
\text { on a one-to-one basis to coach/mentor some of the people through some of the things that I think would help } \\
\text { them do their jobs better. 3) Developing learning culture: [sharing] things that I've read or been on previous } \\
\text { courses the previous week. }\end{array}$ \\
\hline Transfer to wider network & 2 & 1 & $\begin{array}{l}\text { Surprising little evidence exists to show learning was transferred to the wider network, nevertheless, two } \\
\text { examples exist to represent this code: helped [close friend] with some of their ideas; involved with a Chief } \\
\text { Executive and Managing Directors group... swapping stories and working on tasks for each other. }\end{array}$ \\
\hline $\begin{array}{l}\text { Negative response to social } \\
\text { learning }\end{array}$ & 37 & 12 & $\begin{array}{l}\text { This code provides a contrast to antecedents of social learning noted previously in this category. It } \\
\text { incorporates: 1) Issues with group dynamics: [my group were] not like minded; you've got to be lucky in } \\
\text { order to have the right mixture of people to learn off; I have no idea how I could help [shadowing partner] } \\
\text { because I know nothing about retailing whatsoever. 2) Issues with action learning set facilitation: I gained } \\
\text { very little if anything from the action learning sets... I think you'll find ours was a general feeling; it was a } \\
\text { waste of time that was; it depends on who you have in there and who was facilitating it. }\end{array}$ \\
\hline \multicolumn{4}{|c|}{ 4. Emotion and affective learning } \\
\hline \multicolumn{4}{|l|}{ 4.1 Emotional exposure } \\
\hline Financial exposure & 30 & 14 & $\begin{array}{l}\text { The term 'recession' appears } 13 \text { times in the data and other references to the economic climate are prominent, } \\
\text { for example: tough times with the recession; struggling with recession. Others referred explicitly to: } \\
\text { 'cataclysmic events', for example: we had taken a liquidation at the time I started LEAD. }\end{array}$ \\
\hline $\begin{array}{l}\text { Relationship risk (internal, } \\
\text { e.g. staff, partners) }\end{array}$ & 61 & 28 & $\begin{array}{l}\text { This code incorporates relationship risk with 1) Staff: there was a lot of keeping your distance from your staff; } \\
\text { you could walk in that workshop and it was like cutting the atmosphere with a knife. 2) Partners: I've been in } \\
\text { this kind of working environment for years and I've always had to... argue [with partners for a better work- } \\
\text { life balance]. }\end{array}$ \\
\hline $\begin{array}{l}\text { Relationship risk (external, } \\
\text { e.g. suppliers, customers) }\end{array}$ & 7 & 3 & $\begin{array}{l}\text { There are only a few explicit examples of this code, which captures themes such as: it's some sort of ugly } \\
\text { monster... a certain event will trigger it ... if it was a comment a client makes I think about it there and then } \\
\text { and then I'll be thinking about it at } 2 \text { o'clock in the morning; really horrible upsetting wrangling with } \\
\text { companies. }\end{array}$ \\
\hline Social risk & 19 & 9 & $\begin{array}{l}\text { Examples of this code include predominantly include references to the social stigma associated with business } \\
\text { failure: it's a small community and they like to see you fail; everybody thought I was mad. }\end{array}$ \\
\hline Psychological risk & 98 & 46 & $\begin{array}{l}\text { Participants expressed psychological risk in terms of feeling: stressed out; het up; worried; in a 'rut'; and } \\
\text { lonely. }\end{array}$ \\
\hline \multicolumn{4}{|l|}{ 4.2 Affective learning } \\
\hline Enjoyment of learning & 57 & 28 & $\begin{array}{l}\text { Although this code is captured in } 57 \text { instances, terms included appear more frequently in the transcripts. For } \\
\text { example: fun appears } 14 \text { times and enjoy(ed) } 62 \text { times: good fun, really enjoyed...; enjoyable learning curve. }\end{array}$ \\
\hline $\begin{array}{l}\text { Buzz and energy, stimulating, } \\
\text { powerful learning experience }\end{array}$ & 83 & 41 & $\begin{array}{l}\text { Terms such as: fantastic, astounding, emotionally moving, really power, inspirational appeal to the emotional } \\
\text { nature of encounters included in this code. }\end{array}$ \\
\hline Shake-up ('kick up the arse') & 7 & 3 & Although there are few examples of this code, it provides useful insights, for example: she said 'it's sh\#t, \\
\hline
\end{tabular}




\begin{tabular}{|l|r|r|l|}
\hline & & & $\begin{array}{l}\text { don't you realise you don't get no business off it because it's sh\#t' and to hear someone say that it's - and } \\
\text { then I went home that night and looked at it and thought...; phenomenal aid and kick; you sit back when } \\
\text { people actually criticise you. }\end{array}$ \\
\hline Therapeutic & 10 & 5 & $\begin{array}{l}\text { This code includes four references to: 'comfort factor' and other examples include: looking after us and in a } \\
\text { nurturing way; a great support; A problem shared is a problem halved. This has given me the opportunity to } \\
\text { less than half it. }\end{array}$ \\
\hline $\begin{array}{l}\text { Negative emotions concerning } \\
\text { learning }\end{array}$ & 47 & 23 & $\begin{array}{l}\text { In summary, negative emotions include: 1) Frustration: completely irrelevant... nothing useful to take away } \\
\text { with me; some bits total waste of time; [lacked relevance] that was the frustration; fell off a cliff. 2) } \\
\text { Disappointment in some experiences on the programme: that was a pity; I felt really sad for him; bloody } \\
\text { appalling, really were appalling. 2) Overwhelmed: it threw so many things up in the air... and sometimes it } \\
\text { makes you frustrated. 3) Over exposure: } \text { I certainly wouldn't feel comfortable in offloading my business to } \\
\text { somebody. 4) Mourning on completion: disappointed when it finished. }\end{array}$ \\
\hline
\end{tabular}




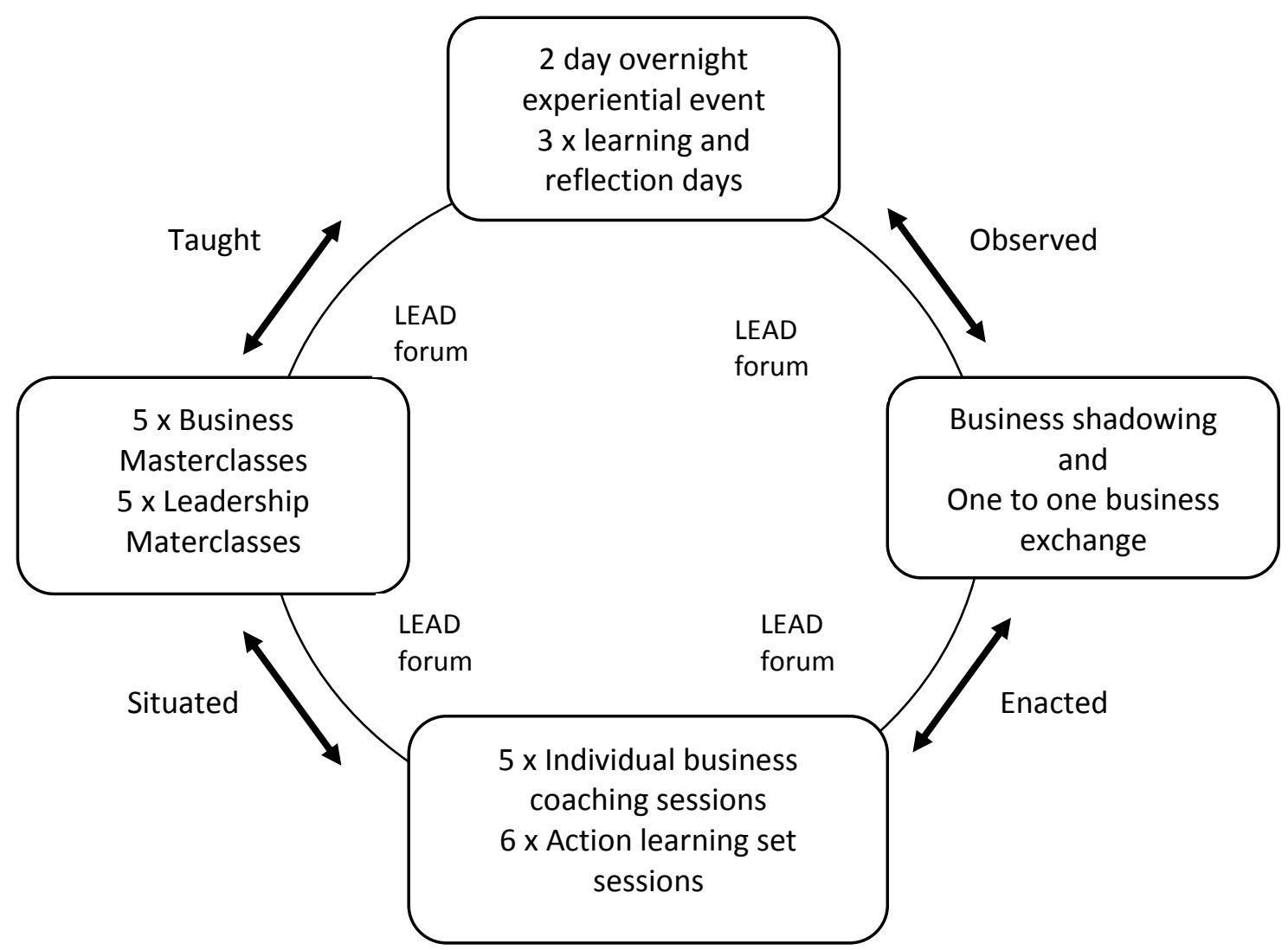

Figure 1. Integrated learning cycle

Adapted from Smith 2011. 
Table 1. First level of thematic coding categories.

(1) Learning by doing

Randomness, experimentation and dynamic aspects

Preparedness to act

Learning tasks

\begin{tabular}{rr} 
N & Per Cent \\
310 & 16 \\
142 & 7 \\
220 & 11 \\
265 & 14 \\
\hline 937 & 48
\end{tabular}

(2) Reflective practices

305

16

(3) Social learning

300

15

(4) Emotions and affective learning Affective learning

Emotional exposure

\begin{tabular}{ll}
215 & 11 \\
\hline 419 & 21
\end{tabular}

